\title{
James Young Simpson, M.A., D.Sc., D.Jur.
}

THE death of Professor J. Y. Simpson on May 20 last removed a distinguished citizen from Edinburgh and an earnest thinker from the ranks of literature. He had returned from a lecturing tour in America in excellent spirits and apparently in normal health, but two days later he was suddenly struck down by illness, and after four more days he passed away without regaining consciousness.

Simpson came of notable ancestors, and was worthy of his heritage. He was the eldest son of Sir Alexander R. Simpson and of a daughter of Barbour of Bonskeid. Born in 1873 , he was educated at George Watson's College and then at the University and New College of Edinburgh. Under the inspiration of Henry Drummond, whose Chair he was afterwards (1904) to be called to fill, he made Biology his special field of study, and in 1899 he was appointed to the Lectureship in Natural Science in the Free Church College at Glasgow.

Simpson was elected a Fellow of this Society in I900, and served on the Council from 1922 to 1925 . The results of his observations on the fission of ciliate protozoa were published in the Proceedings in $190 \mathrm{I}$ and in Biometrika, I902.

In I90I the University of Edinburgh conferred on him the degree of D.Sc. Thereafter, appreciation of his hard and patient work was evidenced in his expanding influence.

His wider influence was gained by activity in two different fields which, however, were not so far apart as they appeared on the surface to be. On the one hand, his published works, especially The Spiritual Interpretation of Nature, and then its sequel, Man and the Attainment of Immortality, established his reputation over wide circles in the Englishspeaking world and even beyond it. On the other hand, his intimate knowledge of Russia and his official post-war work in the adjustment of frontiers between Estonia, Latvia, and Lithuania made him a popular figure in those lands, and won a good name for him as a wise and capable arbiter and administrator. But his science and his politics were more closely linked than might appear, for his scientific interest gained for him an entrance into many Eastern European doors which were apt to be closed to a more ordinary foreigner.

There can be no doubt at all as to the interest which dominated 
Simpson's mind and gave unity to his many diverse activities. He never swerved from his early ambition to continue the work of Henry Drummond in doing something to heal the breach between Science and Religion. He was essentially a frontier man. His arbitration work in the Baltic countries was a parable of his mind. His thoughts moved in the borderland between Science and Religion, and it was his intellectual ambition to assist in the work of arbitration there.

That Nature cannot be interpreted other than spiritually was an early conviction with Simpson, and it grew even stronger with the years. $\mathrm{He}$ hailed with delight the recognition of the spiritual background of Nature by mathematical astronomers like Jeans and Eddington. He himself claimed no competence in Modern Physics, but he interested himself more and more in that bewildering field during his later years, and attained to a quite adequate idea of the lie of the land. He was thus more and more in demand as a lecturer on the relation of Science to Religion, and it is more than possible that his last lectures, delivered during his recent tour in America, took more out of him than he knew, and hastened on his physical collapse.

"J. Y.," as his friends named him, was a very friendly man. In every part of the world there are those who have good reason to be grateful to him and his charming wife for the abounding hospitality of 25 Chester Street. Nor did he lack appreciation of his own Edinburgh, nor fail to rejoice in its appreciation of him. Whether in his Chair in New College, or in the general cause of Education, or in his Church, or in the promotion of any worthy movement, or as one of the most skilful among the Royal Company of Archers, he gave liberally of mind and heart and life to his own city.

D. L. 